\title{
IMMUNIZATION STATUS WITH CHILDREN NUTRITION STATUS IN THE WORKING AREA OF PUSKESMAS KEDAMEAN, GRESIK \\ Zanuba Q Nada ${ }^{1)}$, Dini Andriani ${ }^{2)}$, Benedictus TR Prabantoro ${ }^{3)}$
}

\begin{abstract}
Introduction: Immunization in the national health system is one form of health protection that is very effective in preventing infant and under-five mortality rates. Children who are not immunized do not have immunity against the disease, so they will fall ill, possibly causing a decline in nutritional status. Infectious diseases and immune functions are interconnected and will ultimately affect the nutritional status in children.

Purpose: To determine the correlation between immunization status and nutritional status of children under five in the Health Center Community or Pusat Kesehatan Masyarakat in Indonesian (Puskesmas) in Gresik Regency, East Java.

Method: This study used an observational analytic research method with a cross-sectional research design. The samples of this research are toddlers aged 1-5 years old and mothers who have MCH books. The study was conducted by collecting data using a questionnaire to be filled out by mothers of children under five. Then, the researchers collected data by recording the immunization status of children under five by looking at the $\mathrm{MCH}$ book. Then, we measured the body weight and height of the toddler.

Results: Based on the results of statistical calculations using the chi-square test regarding the analysis of the relationship between immunization status and nutritional status of children under five obtained a significance value of $p=0.220: p \geq 0.05$ (value $\alpha$ ).

Conclusion: There was no significant relationship between immunization status and nutritional status of children under five years old in the Puskesmas Kedamean in Gresik Regency
\end{abstract}

Keywords: Immunization status, nutritional status, children

\footnotetext{
${ }^{1)}$ Student of Faculty of Medicine, Widya Mandala Catholic University Surabaya, Jl. Kalisari Selatan No. 1 Surabaya Email : zanubaqottrunnada1410@gmail.com

2) Pediatric Department, Faculty of Medicine, Widya Mandala Catholic University Surabaya, J1. Kalisari Selatan No. 1 Surabaya

${ }^{3)}$ Obstetric and Gynecology Department, Faculty of Medicine, Widya Mandala Catholic University Surabaya, Jl. Kalisari Selatan No. 1 Surabaya
} 


\section{INTRODUCTION}

Immunization in the national health system is one form of health intervention that is very effective in efforts to reduce infant and under-five mortality rates. The primary basis of preventive health services is a top priority by immunizing a child or toddler, not only providing protection to other children but also increasing public immunity and reducing the spread of infection ${ }^{1}$. The government requires every child to get necessary immunizations that are included in the Immunization Development Program (PPI), including Hepatitis B, BCG, DPT-HB-HiB (pentavalent), Polio, and Measles ${ }^{2}$. What is also meant by complete primary immunization is that every infant (0-11 months old) must get complete primary immunization consisting of $4 \mathrm{x}$ Hepatitis $\mathrm{B}$, 1x BCG, 4x Polio, 3x Pentavalent (DPTHepB-Hib), and 1x Measles / MR ${ }^{4,5,6}$.

The incidence of disease in children under five is very closely related to the child's nutritional status. Nutritional status is a significant health indicator because children under five are a group that is vulnerable to health and nutrition. Children who are not immunized do not have immunity against infectious diseases, so the child will fall ill, possibly causing a decline in nutritional status. Infectious diseases and immune functions are closely related to each other and will ultimately affect nutritional status in the form of a decrease in nutritional status in children ${ }^{3}$. This study aimed to determine the relationship between immunization status and nutritional status of children under five years old in the Health Center Community, or Pusat Kesehatan Masyarakat in Indonesian (Puskesmas), in Gresik Regency, East Java.

Based on data from Puskesmas Kedamean regarding the achievement of nutrition programs covering eight villages in the Kedamean area, there were cases of malnutrition in children under five years old and had received supplementary feeding (PMT). Underweight children under five years old got PMT with a target of $60 \%$, and malnutrition received $100 \%$ care. In Puskesmas Kedamean, most children have received complete basic immunizations. A small number of children who have incomplete immunizations are due to illness during the routine schedule of complete basic immunization $^{7,8}$.

In this study, in addition to examining the history of complete primary immunization status and nutritional status of children under five years old, we also want to know about the essential characteristics of mothers and children under five years old in the working area of the Puskesmas Kedamean, especially in 
Turirejo, Sukorejo, Bunton, Pesemen, and Belahanrejo. Among them are the age and sex of children under five years old, status of daily food intake, snacks, breast milk, milk, and MP-ASI consumed now, and history of infectious diseases, maternal age, socioeconomic status, maternal knowledge, mother's education, and family income.

\section{METHOD}

This study used observational analytic research methods with a crosssectional research design. This crosssectional study design was used to determine the relationship between immunization status and nutritional status of children under five years old in the Puskesmas Kedamean, Gresik.

The total population measured in this study was 114 pairs of mothers and children under five. However, there were 27 research respondents whose data could not be used because respondents did not complete the questionnaire, thus could not be included in the study. The sample data used in this study were 87 respondents. The immunization status sampling technique in this study was purposive sampling; this method uses criteria that have been selected by researchers in selecting samples. The sample selection criteria are divided into inclusion and exclusion criteria.
Inclusion Criteria are:

1) Children under the age of 1 - 5 years old in the Puskesmas Kedamean.

2) Mother has an MCH book.

3) Mothers are willing to take part in the research.

Exclusion Criteria are:

1) Children under five who are sick

2) Children under five with congenital abnormalities. Whereas, the sampling technique for nutritional status in this study was non-probability sampling that is using consecutive sampling.

\section{RESULTS}

Table 1. Distribution of Children by Age on September 7 - September 14, 2019

\begin{tabular}{llll}
\hline No. & \multicolumn{1}{c}{ Age } & $\boldsymbol{n}$ & $\mathbf{\%}$ \\
\hline 1. & $<2$ year & 37 & 42,5 \\
2. & $>2$ year & 50 & 57,5 \\
\hline Total & & 87 & 100 \\
\hline
\end{tabular}

Based on Table 1, the highest number based on the age of children under five years old who were respondents of this study were aged $>2$ years old, 50 respondents or $57.5 \%$.

Table 2. Distribution of Children by Gender on September 7 - September 14 2019

\begin{tabular}{llcc}
\hline No. & Gender & $\boldsymbol{n}$ & $\mathbf{\%}$ \\
\hline 1. & Male & 39 & 44,8 \\
2. & Female & 48 & 55,2 \\
\hline
\end{tabular}




\begin{tabular}{lll}
\hline Total & 87 & 100 \\
\hline
\end{tabular}

Based on Table 2, the sex data of children under five who participated in this study were 48 females or $55.2 \%$ and 50 males or $44.8 \%$.

Table 3. Distribution of Mothers by Age on 7 September - 14 September 2019

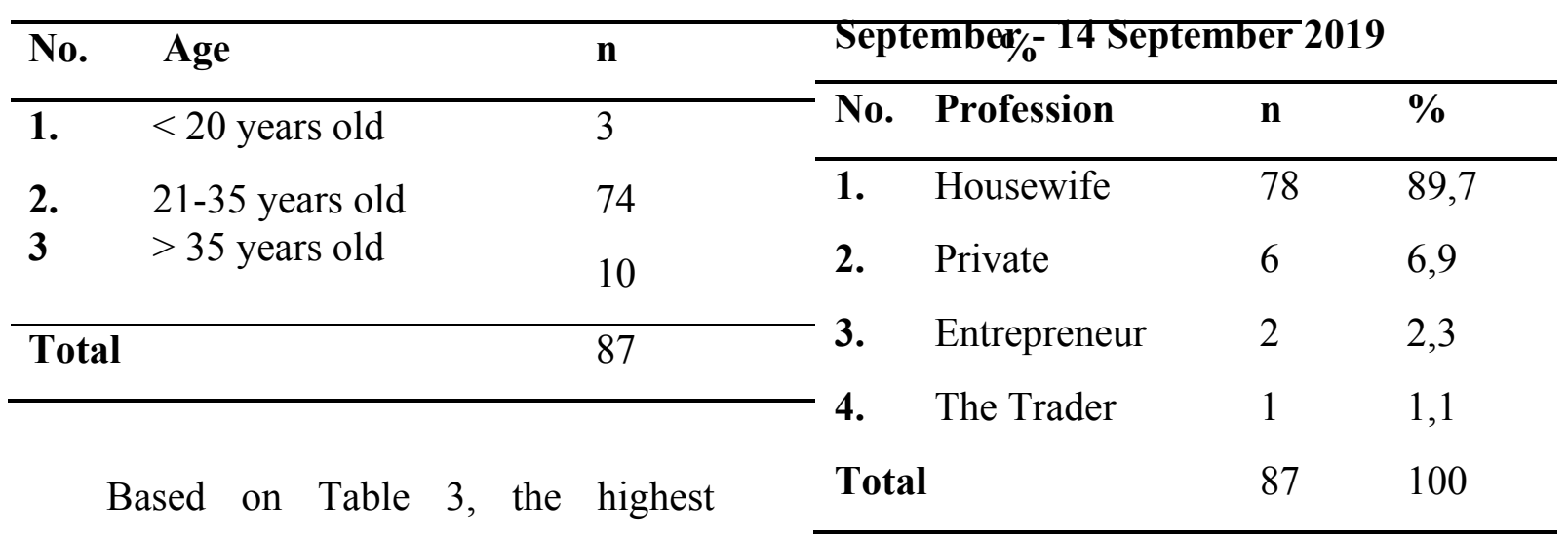

number based on the age of mothers who participated in this study was 21-35 years old as many as 74 respondents or $85.1 \%$.

Table 4. Distribution of Samples by Mother's Level of Education on September 7 - September 142019

\begin{tabular}{|c|c|c|c|}
\hline No. & $\begin{array}{l}\text { Level } \\
\text { Education }\end{array}$ & $\mathbf{n}$ & $\%$ \\
\hline 1. & Primary School & 6 & 6,9 \\
\hline 2. & $\begin{array}{l}\text { Junior High } \\
\text { School }\end{array}$ & 29 & 33,3 \\
\hline 3. & $\begin{array}{l}\text { Senior High } \\
\text { School }\end{array}$ & 45 & 51,7 \\
\hline 4. & Bachelor & 7 & 8,1 \\
\hline \multicolumn{2}{|c|}{ Total } & 87 & 100 \\
\hline
\end{tabular}

Based on Table 4, the most number based on the education level of mothers of children under five years old who were respondents of this study were mothers with high school education levels of 45 respondents or $51.7 \%$.

Table 5. Distribution of Samples by Occupational Mother of Children on 7 September/\%-14 September 2019

Based on Table 5, the highest number based on the work of mothers of children under five years old who became respondents of this study were mothers with occupations of housewives numbering 78 respondents or $89.7 \%$.

Table 6. Distribution of Samples Based on Family Income of children under five years old on 7 September $\quad 14$ September 2019

\begin{tabular}{llcc}
\hline No. & Family Income & n & \% \\
\hline 1. & $<$ Rp. 3.000 .000 & 69 & 79,3 \\
2. & $>$ Rp. 3.000.000 & 18 & 20,7 \\
\hline Total & 87 & 100 \\
\hline
\end{tabular}


Based on Table 6 , the most number based on family income of children under five who become respondents of this study are families with income $<\mathrm{Rp} 3,000,000$ totaling 69 respondents or $79.3 \%$.

Table 7. Distribution of Children by Basic Immunization Status from 7 September to 14 September 2019

\begin{tabular}{llll}
\hline No. & $\begin{array}{l}\text { Immunization } \\
\text { Status }\end{array}$ & $\mathbf{n}$ & $\mathbf{\%}$ \\
\hline 1. & Complete & 71 & 81,6 \\
2. & Incomplete & 16 & 18,4 \\
\hline \multicolumn{2}{l}{ Total } & 87 & 100 \\
\hline
\end{tabular}

Based on Table 7. , the basic immunization status data of children under five who participated in this study were children under five with complete immunization status,71 respondents or $81.6 \%$ and with incomplete immunization status, 16 or $18.4 \%$ caused by children who got sick when they were going to be be given basic immunizations according to the basic immunization schedule, so they must be postponed until they are healthy, which results in the incompleteness of basic immunization in these toddlers.
Table 8. Distribution of Children by Nutrition Status on September 7 September 142019

\begin{tabular}{|c|c|c|c|c|}
\hline No. & $\begin{array}{l}\text { Z- } \\
\text { scores }\end{array}$ & $\begin{array}{l}\text { Nutritional } \\
\text { Status }\end{array}$ & n & $\%$ \\
\hline 1. & $<-3 \mathrm{SD}$ & Very Thin & 2 & 2,3 \\
\hline 2. & $\begin{array}{l}-3 \text { SD } \\
\text { to }<-2 \\
\text { SD }\end{array}$ & Thin & 4 & 4,6 \\
\hline 3 & $\begin{array}{lr}-2 & \mathrm{SD} \\
\text { to } & 2 \\
\mathrm{SD} & \end{array}$ & Normal & 71 & 81,6 \\
\hline 4 & $>3 \mathrm{SD}$ & Fat & 10 & 11,5 \\
\hline Tota & & & 87 & 100 \\
\hline
\end{tabular}

Based on Table 8, the highest number based on the nutritional status of children under five years old who were respondents of this study were children under five years old with normal nutritional status as many as 71 respondents or $81.6 \%$ and the least number of children under five years old with very thin nutritional status,two respondents or $2.3 \%$.

Table 9. Distribution of Daily Food Intake of Toddlers on September 7 September 14, 2019 


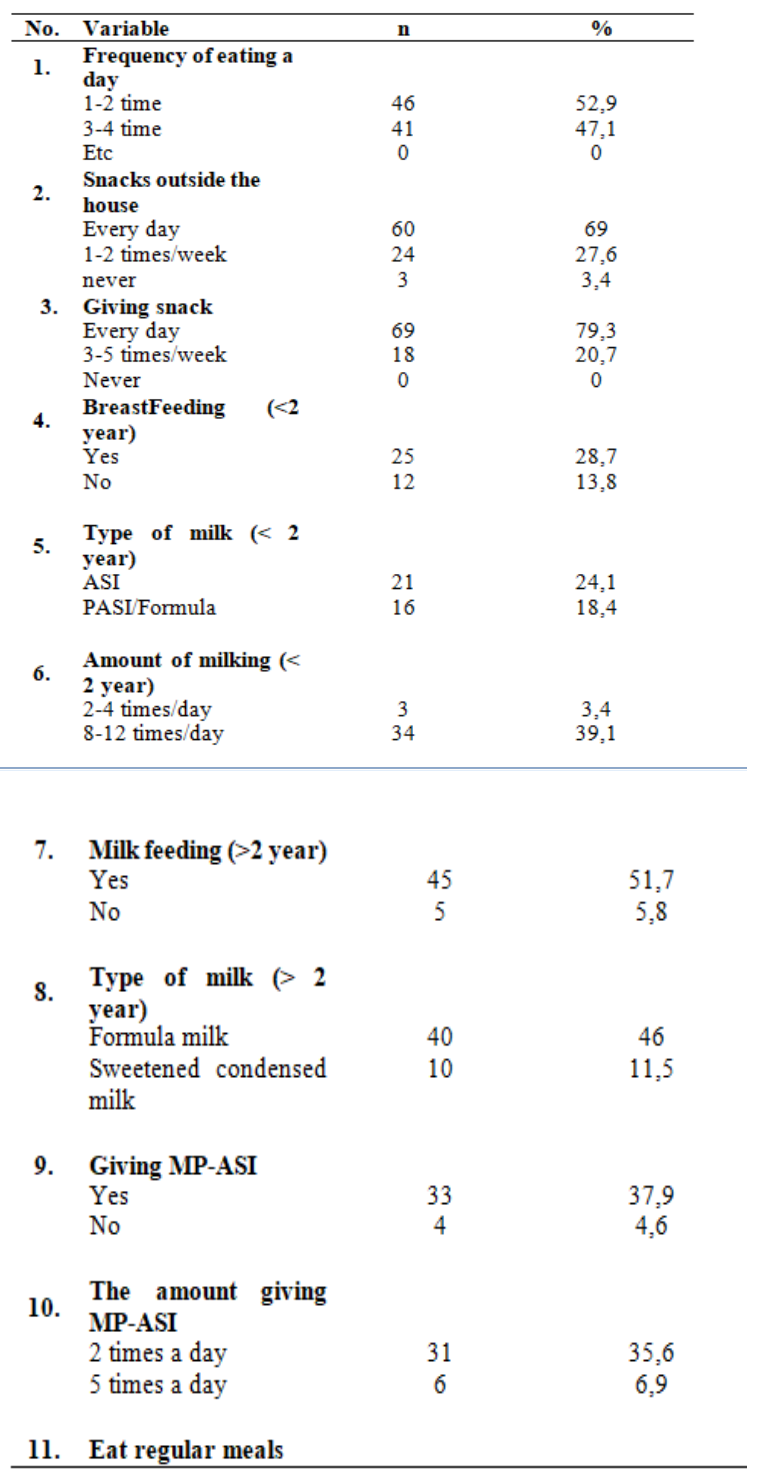

\begin{tabular}{lcc} 
Yes & 84 & 96,6 \\
No & 3 & 3,4 \\
12. $\begin{array}{l}\text { Amount of staple food } \\
\text { portions }\end{array}$ & & \\
1 adult plate & 12 & 13,8 \\
$\begin{array}{l}\text { 2 Centong } \\
\text { Lain-Lain (Setengah }\end{array}$ & 20 & 23 \\
Centong) & 55 & 63,2 \\
13. & & \\
Yospitalized & 22 & 25,3 \\
Yes & 65 & 74,7 \\
No Check into a health & & \\
14. facility in one year & 36 & 41,4 \\
$1-2$ times & 25 & 28,7 \\
>2 times & 26 & 29,9 \\
\hline Never & & \\
\hline
\end{tabular}

Table 9 shows the results of an analysis of the essential characteristics of the research subjects in the form of a questionnaire containing daily food intake and a history of infection of children under five. on the variable frequency of eating a day, the highest number was 1-2 times as many as 46 respondents or $52.9 \%$. on the frequency of snacks outside the home, the highest was every day, 60 or $69 \%$ on the variable of breastfeeding for toddlers aged $<2$ years old, the most common answer was Yes, as many as 25 respondents or $28.7 \%$. on the variable type of milk given, the most common was breastfeeding as many as 21 respondents or $21 \%$. on the frequency of breastfeeding variable, the highest was 8-12 times/day as many as 34 respondents or $39.1 \%$. on the variable giving milk to children under the age of $>2$ years old, most answered Yes,45 respondents or $51.7 \%$. on the variable type of milk given the most common was formula milk, as many as 40 respondents or $46 \%$. on the variable giving of MP-ASI to toddlers aged $<2$ years old, the most answered Yes, as many as 33 respondents or $37.9 \%$. Based on the frequency of MPASI the highest was two times a day, as many as 31 respondents or $35.6 \%$. Based on the variable portion of regular meals, the most number was others as many as 55 respondents or $63.2 \%$. Based on the variable hospitalization, most answered no, as many as 65 respondents or $74.7 \%$. Based on the variable check into health facilities in a year, the highest number was 
1-2 times, as many as 36 respondents or $41.4 \%$.

Table 10. Correlation between Immunization Status and Nutrition Status of Children

\begin{tabular}{ccccc}
\hline Variable & \multicolumn{2}{c}{ Breastfeeding } & Total & p \\
\hline $\begin{array}{c}\text { Nutritional } \\
\text { status } \\
\text { Very Thin }\end{array}$ & Yes & No & & \\
& $(50 \%)$ & $(50 \%)$ & $(100,0 \%)$ & \\
Thin & 2 & 3 & 5 & 0,179 \\
& $(40 \%)$ & $(60 \%)$ & $(100,0 \%)$ & \\
Normal & 11 & 9 & 20 & \\
& $(55 \%)$ & $(45 \%)$ & $(100,0 \%)$ & \\
Fat & 8 & 2 & 10 & \\
& $(80 \%)$ & $(20 \%)$ & $(100,0 \%)$ & \\
\hline Total & 22 & 15 & 37 & \\
& $(59,46 \%)$ & $(40,54 \%)$ & $(100,0 \%)$ &
\end{tabular}

Based on the analysis of the relationship between immunization status and nutritional status of children under five years old, the significance value of $p=$ 0.220: $\mathrm{p} \geq 0.05$ ( $\alpha$ value) was obtained. This result shows no significant correlation between the history of immunization status and the nutritional status of children under five years old.

Table 11. Correlation between Family Income and Nutritional Status of Children

\begin{tabular}{|c|c|c|c|c|}
\hline Variable & \multicolumn{2}{|c|}{ Family income } & \multirow[t]{2}{*}{ Total } & \multirow[t]{2}{*}{$\mathbf{p}$} \\
\hline $\begin{array}{c}\text { Nutritional } \\
\text { Status }\end{array}$ & $\begin{array}{c}\text { < Rp. } \\
3.000 .000\end{array}$ & $\begin{array}{l}\text { >Rp. } \\
3.000 .000\end{array}$ & & \\
\hline Very thin & $\begin{array}{c}2 \\
(100,0 \%)\end{array}$ & $\begin{array}{c}0 \\
0 \%)\end{array}$ & $\begin{array}{c}2 \\
(100,0 \%)\end{array}$ & \\
\hline Thin & $\begin{array}{c}4 \\
(100,0 \%)\end{array}$ & $\begin{array}{c}0 \\
(0 \%)\end{array}$ & $\begin{array}{c}4 \\
(100,0 \%)\end{array}$ & 0.000 \\
\hline Normal & $\begin{array}{c}55 \\
(77,5 \%)\end{array}$ & $\begin{array}{c}16 \\
(22,5 \%)\end{array}$ & $\begin{array}{c}71 \\
(100,0 \%)\end{array}$ & \\
\hline Fat & $\begin{array}{c}9 \\
(90 \%)\end{array}$ & $\begin{array}{c}1 \\
(10 \%)\end{array}$ & $\begin{array}{c}10 \\
(100,0 \%)\end{array}$ & \\
\hline Total & $\begin{array}{c}70 \\
(80,46 \%)\end{array}$ & $\begin{array}{c}17 \\
(19,54 \%)\end{array}$ & $\begin{array}{c}87 \\
(100,0 \%)\end{array}$ & \\
\hline
\end{tabular}

Based on the analysis of the relationship between family income and nutritional status of children under five years old, the significance value of $\mathrm{p}=$ 0,000: $\mathrm{p} \leq 0.05$ ( $\alpha$ value) was obtained, which shows that family income can affect the nutritional status of children under five years old.

Table 12. Correlation between Mother's Education Level and Nutritional Status of Toddler Children

\begin{tabular}{|c|c|c|c|c|c|c|}
\hline \multirow{2}{*}{$\begin{array}{c}\text { Variable } \\
\begin{array}{c}\text { Nutritional } \\
\text { status }\end{array}\end{array}$} & \multicolumn{4}{|c|}{ Mother's Education Level } & \multirow[t]{2}{*}{ Total } & \multirow[t]{2}{*}{ p } \\
\hline & $\begin{array}{r}\text { Primary } \\
\text { School }\end{array}$ & $\begin{array}{c}\text { Junior } \\
\text { High } \\
\text { School }\end{array}$ & $\begin{array}{l}\text { Senior } \\
\text { High } \\
\text { School }\end{array}$ & Bachelor & & \\
\hline Very thin & $\begin{array}{c}0 \\
(0 \%)\end{array}$ & $\begin{array}{c}2 \\
(100,0 \%)\end{array}$ & $\begin{array}{c}0 \\
(0 \%)\end{array}$ & $\begin{array}{c}0 \\
(0 \%)\end{array}$ & $\begin{array}{c}2 \\
(100,0 \%)\end{array}$ & \\
\hline Thin & $\begin{array}{c}1 \\
(25 \%)\end{array}$ & $\begin{array}{c}1 \\
(25 \%)\end{array}$ & $\begin{array}{c}2 \\
(50 \%)\end{array}$ & $\begin{array}{c}0 \\
(0 \%)\end{array}$ & $\begin{array}{c}4 \\
(100,0 \%)\end{array}$ & 0.000 \\
\hline Normal & $\begin{array}{c}6 \\
(8,11 \%)\end{array}$ & $\begin{array}{c}21 \\
(28,38 \%)\end{array}$ & $\begin{array}{c}54 \\
(79,97 \%)\end{array}$ & $\begin{array}{c}6 \\
(8,11 \%)\end{array}$ & $\begin{array}{c}74 \\
(100,0 \%)\end{array}$ & \\
\hline Fat & $\begin{array}{c}0 \\
(0 \%)\end{array}$ & $\begin{array}{c}3 \\
(42,86 \%)\end{array}$ & $\begin{array}{c}4 \\
(57,14 \%)\end{array}$ & $\begin{array}{c}0 \\
(0 \%)\end{array}$ & $\begin{array}{c}7 \\
(100,0 \%)\end{array}$ & \\
\hline Total & $\begin{array}{c}7 \\
(8,06 \%)\end{array}$ & $\begin{array}{c}27 \\
(31,03 \%)\end{array}$ & $\begin{array}{c}60 \\
(68,97 \%)\end{array}$ & $\begin{array}{c}6 \\
6,89 \%)\end{array}$ & $\begin{array}{c}87 \\
(100,0 \%)\end{array}$ & \\
\hline
\end{tabular}

Based on the correlation between maternal education level and nutritional status of children under five years old, the significance value of $p=0,000: p \leq 0.05(\alpha$ value) was obtained, which shows that the mother's education level can affect the nutritional status of children under five years old.

Table 13. Correlation between immunization status with the nutritional status of toddlers 


\begin{tabular}{|c|c|c|c|c|}
\hline Variable & \multicolumn{2}{|c|}{ Immunization Status } & Total & p \\
\hline Nutritional status & Complete & Incomplete & & \\
\hline Very thin & $\begin{array}{c}2 \\
(100,0 \%)\end{array}$ & $\begin{array}{c}0 \\
(0 \%)\end{array}$ & $\begin{array}{c}2 \\
(100,0 \%)\end{array}$ & \\
\hline Thin & $\begin{array}{c}4 \\
(100,0 \%)\end{array}$ & $\begin{array}{c}0 \\
(0 \%)\end{array}$ & $\begin{array}{c}4 \\
(100,0 \%)\end{array}$ & 0,220 \\
\hline Normal & $\begin{array}{c}55 \\
(77,5 \%)\end{array}$ & $\begin{array}{c}16 \\
(22,5 \%)\end{array}$ & $\begin{array}{c}71 \\
(100,0 \%)\end{array}$ & \\
\hline Fat & $\begin{array}{c}10 \\
(100,0 \%)\end{array}$ & $\begin{array}{c}0 \\
(0 \%)\end{array}$ & $\begin{array}{c}10 \\
(100,0 \%)\end{array}$ & \\
\hline Total & $\begin{array}{c}71 \\
(81,6 \%)\end{array}$ & $\begin{array}{c}16 \\
(18,4 \%)\end{array}$ & $\begin{array}{c}87 \\
(100,0 \%)\end{array}$ & \\
\hline
\end{tabular}

Based on the analysis results, the correlation between immunization status in and the nutritional status of children under five obtained no significant relationship between immunization status and nutritional status of children under five years old in the Puskesmas Kedamean in Gresik Regency.

\section{DISCUSSION}

In this study, the results of the analysis in Table 13 shows that there is no significant correlation between the history of immunization status with nutritional status of children under five. They are supported by research conducted by Barina L. Pusung, Nancy S.H. Malonda, and Nita Momongan regarding the relationship between immunization history and infectious disease with nutritional status in toddlers aged 24-59 months in the Toulagai Health Center working area of Southeast Minahasa Regency. This study uses a correlation method with a crosssectional approach. Respondents are mothers who have children aged 24 - 59 months as many as 100 people in the work area of the ToulUHAN Health Center. The $\mathrm{p}$-value 0.950 results show that there is no relationship between the history of immunization and nutritional status (BW / $\mathrm{U}, \mathrm{TB} / \mathrm{U}, \mathrm{BW} / \mathrm{TB}$ ) in infants aged 24-59 months . However, this study differs from the results of research conducted by Vindya Vindriana, Abdul Kadir, and M. Askar. They researched the correlation of immunization completeness with nutritional status in children aged 1-5 years in Watonea Village Work Area Katobu Health Center, Muna Regency, on July 12 - 20 July 2012. The population in this study were toddlers aged 1-5 years who were registered in the Watonea village working area of the Katobu Community Health Center in Muna Regency as many as 229 children.Determination of sample size by using the formula obtained 70 respondents according to inclusion criteria. This type of non-experimental research uses a descriptive observational method with a cross-sectional approach; the sampling technique is a simple random sampling; data collection is done by questionnaire and observation sheet. The collected data is processed and analyzed using Microsoft Excel and computer programs (SPSS) version 16.0. Data analysis includes Univariate and Bivariate analysis methods using the Chi-Square test. The results showed that completeness of immunization had a significant 
relationship with health status $(\mathrm{p}=0.001)$, health status had a significant relationship with nutritional status $(\mathrm{p}=0,000)$, so completeness of immunization was indirectly related to nutritional status $(\mathrm{p}=$ $0,000)$. The study concludes that there is a significant relationship between immunization completeness, health status, and nutritional status. The more complete the immunization, the better the health status so that nutritional status also tends to be better ${ }^{9,10,11}$.

\section{CONCLUSION}

Based on the results of research conducted on the correlation between immunization status and nutritional status of children under five years old in the Puskesmas Kedamean, which includes Turirejo, Sukorejo, Bunton, Pesemen, and Belahanrejo on 87 samples of mother and toddlers who meet the inclusion criteria and exclusions from 7 September to 14 September 2019. From this study conclusions can be drawn as follows:

1) Obtained basic immunization status data for children under five years old who participated in this study were children under five with complete immunization status as many as 71 respondents or $81.6 \%$ and children under five with incomplete immunization status as many as 16 or $18.4 \%$ caused by illness due to infants when the basic immunization schedule will give basic immunization so it must be postponed until the toddler is healthy, which results in the incompleteness of basic immunization in the toddler.

2) Obtained the nutritional status data of children under five who participated in this study most had normal nutritional status of 71 respondents and the least was children with fragile nutritional status of two respondents. The number of children under five who have a fragile nutritional status of 2 respondents nutritional status of obese ten respondents.

3) It was found that there was no significant relationship between immunization status and nutritional status of children under five years old in the Puskesmas Kedamean in Gresik Regency.

\section{Acknowledgement}

Author thank:

1. Head of Kesbangpol Kab. Gresik, Head of District Health Office. Gresik

2. Dr. Hilda Betsy MR as the Head of Kedamean Health Center UPT Kec. Kedamean District. Gresik

3. Puskesmas Kedamean

4. Friends of class 2016 Faculty of Medicine Widya Mandala Catholic University of Surabaya 


\section{REFERENCES}

1. Rafentri, Afrilia Ragemi. Factors Related to Mother's Action in Completing Basic Immunization of Polio in Infants in the Work Area of the Seberang Padang Puskesmas. 2016. Padang; Andalas University e-thesis; 2016. 1-13.

2. Heriyanti, Rahma. Relationship between Mother's Knowledge of Basic Immunization and Completeness of Basic Infant Immunization in Watuwoha Village, Aere Public Health Center, Kolaka Timur Regency. Kendari: Kendari Health Polytechnic Department of Midwifery; 2017. 6: 5-9.

3. Basic Health Research. Main Riskesdas Results. 2018.

4. Yunis T, Wahyono M. "Improving the Coverage and Quality of Immunization" from: http: //www.depkes.go.id/resources/dow nload/info- Available up-to-date / pre-rakerkesnas 2018 Experts on Immunization.pdf, accessed in April 2019 at 10:27.

5. Vindriana V, Kadir A, Askar M. Relationship with Completeness of Immunization and Nutritional Status in Toddlers Aged 1-5 Years in Watonea Village, Katobu
Community Health Center, Muna Regency. Makassar: Stikes Nani Hasanuddin Makassar; 2012. 1: 18.

6. Hanum Marimbi. Growth and Development, Nutrition Status, and Basic Immunization 6. In Toddlers. First printing. Editor: Kristiyanasari W. Yogyakarta: Nuhamedika; 2010. 109.

7. Proverawati A, Citra A. Immunization and Vaccination. Matter: First. Yogyakarta: Nuha Medika; 2010.

8. Handinegoro SRS. Guidelines for Immunization in Indonesia. Matter: Sixth. Editor: Dwinandiyo D et al. Jakarta: Indonesian Pediatrician Association Publishing Agency; 2017.

9. Ministry of Health. Give Children Complete Routine Immunizations. Accessed Saturday 28 April. 2018.

10. Fidiantoro, Nungki, Tedy S. Model of Determination of Toddler Nutrition Status in Puskesmas. ejournal Bachelor of Informatics Engineering. 2013.

11. Ministry of Health of the Republic of Indonesia. Mother and Child Health Book. Jakarta: Ministry of Health and JICA; 2017. 67-70 